\title{
The Effectiveness of Giving Plant PGPR Rhizosphere Bamboo on Cocoa Seeds Germination at The Nursery Level
}

\author{
Muhammad Yusril Hardiansyah*, Yunus Musa, Abdul Mollah Jaya \\ Department of Agronomy, Faculty of Agriculture, Universitas Hasanuddin, \\ Jl. Perintis Kemerdekaan KM. 10 Tamalanrea Indah, Makassar, Indonesia. \\ Corresponding author* \\ yusrilhardiansyah1@gmail.com
}

Manuscript received: 27 September, 2020. Revision accepted: 26 June, 2021. Published: 01 July, 2021.

\begin{abstract}
The low productivity of cocoa plantations in Indonesia is partly due to the low quality of seeds, which refers to the impeded growth of cultivated cocoa nurseries. Seed is the initial growth of plants so the importance of giving special treatment to seeds will refer to better seed growth. Provision of Plant Growth Promoting Rhizobacteria (PGPR) microbes can produce indoleacetic acid (IAA) in plants to improve the quality of plant growth. This study aims to determine the effectiveness of the provision of Plant Growth Promoting Rhizobacteria bamboo rhizosphere against cocoa seed germination. The study was carried out in the farmer group garden, Gantarangkeke District, Bantaeng. This study was arranged in the form of a two-factor factorial design (F2F) in a randomized block design (RBD). The use of cocoa seed type as the first factor consisted of GTB (Gantarangkeke Bantaeng) local cocoa seed and MCC 01 cocoa seed and seed immersion treatment at PGPR rhizosphere bamboo concentration as the second factor consisting of $0 \%$ (control) concentration, $5 \%, 10 \%$ and $15 \%$. The results obtained indicate that administration of seeds with bamboo rhizosphere PGPR affects the germination (100.00\%), the speed of seed growth $(7.14 \% /$ etmal), as well as on abnormal seeds $(10.00 \%)$. So that the provision of bamboo rhizosphere PGPR on cocoa seeds has an effective influence on seed germination and cocoa seedling development.
\end{abstract}

Keywords: Cocoa Seed; Plant Growth Promoting Rhizobacteria; Seedbed.

\section{INTRODUCTION}

The soaring increase in world cocoa demand is due to the increasing demand for cocoa beans which is getting higher every year. The annual world demand for cocoa reaches 6.7 million tons and only 2.5 million tons can be met. This means that there are still more than 4 million tons to meet the increasing market needs, so that this can still be an opportunity for Indonesia, especially South Sulawesi (Yusniar, 2013).

Cocoa (Theobroma cacao L.) is a strategic commodity which ideally is able to play a maximum role in increasing farmers' income in Indonesia. This can happen because cocoa has always had a good price development in meeting market needs. However, the reality is that even though every year there is an increase in the planting area, it cannot increase production. The average farmer production is only $1 / 5$ of the potential productivity of the cocoa plant, which ranges from 1.2 3 tonnes/ha (Junaedi, et al., 2017). Of course, these results are still far from expectations because of the many obstacles that occur in the cocoa cultivation process.

One of the factors thought to be the main cause of the low productivity of cocoa plantations in Indonesia is the low quality of seeds which refers to the inhibition of growth in the vegetative phase of cultivated cocoa (Mertade \& Basri, 2011; Sugiharti, 2006). In general, farmers in Indonesia cultivate cocoa using seeds derived from beans. Although generative seeding using seeds is easy to do and can be produced in large quantities at low cost, seedlings of cocoa using seeds will produce genetically non-uniform plants. This is because cocoa is a cross-pollinating crop (Li et al., 1998).

This statement indicates the emergence of a problem currently being faced, namely whether to increase cocoa production to meet cocoa needs in the future, while the availability of good quality plant vegetative phase conditions is currently difficult to obtain. Cultivation of cocoa starts from the nursery stage or the vegetative phase and from this stage will determine the success of plants in the generative phase. During this nursery period, good quality seeds must be obtained so that they will be used as a benchmark for optimum growth and produce fruit and good quality cocoa beans in the future. Of course, in order to get quality seeds, the selection or use of good seeds in germination will be a major factor. One way to get good seeds is by soaking or soaking the seeds. Soaking is a hydration activity slowly before the seeds are germinated so that the potential of seed water reaches a balance to activate metabolic activities in the 
seeds to improve germination and seed growth (Rouhi et al., 2011).

The immersion treatment can be combined with the provision of biological agents capable of improving the quality of seed germination, for example with microbes that are capable of producing growth hormones in plants. One of the microbes that can be used is the microbes that come from Plant Growth Promoting Rhizobacteria (PGPR) as a hormone for plants that can provide more nutrients to spur plant growth in the vegetative phase of plants.

The use of PGPR in this plant is proven from several research results that have been conducted. The results of research by Baihaqi, et al. (2018) show that the use of PGPR on cucumber plants can increase plant growth from 68.6 to $77.7 \%$ compared to without PGPR. Other research on plantation crops, namely the results of research from Widyaningrum (2017) shows that the application of PGPR can increase root length, number of roots, number of leaves, plant height, total dry weight, shoot root ratio, seed steadfastness and robusta coffee seed quality index.

In the rhizosphere or bamboo roots there are Pseudomonas flourenscens bacteria and Bacillus polymixa bacteria which can help the decomposition process (decomposer). The bamboo root PGPR bacteria can secrete a liquid that can dissolve minerals so that they become available nutrients, break down and decompose organic matter (decomposition of organic matter) into plant nutrients. In addition, the Pseudomonas fluorenscens and Bacillus polymixa bacteria can release enzymes and substances that are useful to stimulate plant growth and release antibiotics that can inhibit the growth and development of pathogenic microbes (microbes that cause disease) (Efendi, 2011).

Research on the presence and diversity of microbes in the rhizosphere of bamboo plants has been conducted by several previous researchers. According to Baharuddin et al. (2007) found antagonistic bacteria such as Pseudomonas flourences, Bacillus subtilis and Streptomyces in the roots of healthy bamboo plants. Meanwhile, research conducted by Asniah (2013) showed that the inoculation of fungi from bamboo root soil into the nursery soil had a significant effect on increasing the wet weight of broccoli plants.

This study aims to obtain data and information on the effectiveness of giving Plant Growth Promoting Rhizobacteria rhizosphere of bamboo against cocoa seed germination. Information from the results of this study is expected to be a solution for cocoa farmers in improving their cultivation systems, especially in the nursery phase.

\section{METHODS}

This research was conducted at the Talaka Farmer Group Garden, Gantarangkeke District, Bantaeng
Regency. This research took place from August to November 2019. The tools used were 30 liter buckets, hoes, shovels, scissors, knives, machetes, rulers, meters, calipers, pH meters, carts, analytical scales, sprayers, scales, jerry cans, funnels, aqua plastic bottles, hoses, stoves, pans, paranets, cloths, plastic cups, brown envelopes, millimeter paper blocks, cameras, signage, matches, and writing instruments. The materials used were soil samples from the research location, local GTB (Gantarangkeke Bantaeng) cocoa seeds, MCC 01 clone cocoa seeds, bamboo rhizosphere (Bambusa blumeana), molasses, bran, raw shrimp paste, rice water, water, husk charcoal, sawdust, clear plastic, dab of soap, polybags $12 \times 17 \mathrm{~cm}$, label paper, dolomite and label paper.

The study was conducted using a Two-Factor Factorial Design (RF2F) in a Randomized Block Design (RBD) as an environmental design. This research consists of 2 factors. The first factor is the type of cocoa seed (b) which consists of: local cocoa seeds GTB (Gantarangkeke Bantaeng) (b1) and cocoa seeds clone MCC 01 (b2), while for the second factor is the initial soaking of seeds with PGPR solution for cocoa seeds. with various concentrations of seed priming (k) consisting of: $0 \%$ concentration $(0 \mathrm{ml}$ of PGPR solution or $1000 \mathrm{ml}$ of water), $5 \%$ concentration (50 ml of PGPR + $950 \mathrm{ml}$ water), $10 \%$ concentration (100 ml of PGPR + solution $900 \mathrm{ml}$ of water) and a concentration of $15 \%$ (150 ml of PGPR solution $+850 \mathrm{ml}$ of water). The flow of this research includes making a plant growth promoting rhizobacteria solution which is carried out by taking bamboo rhizosphere then growing it by fermentation process in a container for 14 days, preparing the seeds by selecting seeds from mother pods of MCC 01 and GTB cocoa then separating the placenta from the seeds. Giving of PGPR solution to cocoa seeds (initial soaking of cocoa seeds) simultaneously according to the treatment for 18 hours (Ratnawati et al., 2013), preparation of sprouts media using sterile cloth and sawdust, planting in seedbeds (seedbeds), maintenance and observation.

Observation parameters in this study are as follows:

1. Germination Capacity (\%), measurement based on observing the number of normal germinated seeds marked with cotyledons on the raised seed. Calculation of germination that is on day 7 and day 14 (Deptisari et al., 2018). Sprouts are calculated using the formula:

$$
\mathrm{DB}=\frac{\sum \text { KN Observation I }+\sum \text { KN Observation II }}{\text { Number of Seedlings Planted }} \times 100 \%
$$

Information:

DB : Germination Capacity (\%)

$\sum \mathrm{KN}$ Observation I : The number of sprouts is normal on the 7th day

$\sum \mathrm{KN}$ Observation II $\quad$ : The number of sprouts is normal on the 14th day 
2. Seed Growth Speed (\%/etmal), measurement based on observing the number of normal germinating seeds every day until the day 14 and expressed on a percent scale (Tefa, 2017). Seed growth rate is calculated using the formula:

$$
K C T=\left(\% \frac{K N}{\text { etmal }}\right)=\sum_{0}^{t n} \frac{N}{t}
$$

Information:

$$
\begin{array}{ll}
t & : \text { Observation time } \\
N & : \text { Percentage of normal sprouts every time } \\
& \text { of observation }
\end{array}
$$

3. Abnormal Seeds (\%), measurement based on observing the number of seeds that germinate abnormally. Observation of abnormal seeds is carried out on the day 14 after the nursery (Deptisari et al., 2018). Abnormal seeds are calculated using the formula:

$$
\text { Abnormal Seeds }=\frac{\sum \text { Abnormal Seeds }}{\text { Number of Seedlings Planted }} \times 100 \%
$$

\section{RESULT AND DISCUSSION}

The results showed that the use of two types of cocoa seeds in the initial soaking treatment of seeds with PGPR with seed concentration and the interaction of

\begin{tabular}{|c|c|c|c|}
\hline Treatment & $\begin{array}{l}\text { Germination Capacity } \\
(\%)\end{array}$ & $\begin{array}{l}\text { Seeds Growth Speed } \\
\text { (\%/etmal) }\end{array}$ & $\begin{array}{l}\text { Abnormal Seeds } \\
(\%)\end{array}$ \\
\hline GTB local seeds + PGPR concentration $0 \%$ & $90,00^{\mathrm{d}}$ & $6,43^{b}$ & $10,00^{\mathrm{a}}$ \\
\hline GTB local seeds + PGPR concentration $5 \%$ & $90,00^{\mathrm{d}}$ & $6,43^{\mathrm{b}}$ & $10,00^{\mathrm{a}}$ \\
\hline GTB local seeds + PGPR concentration $10 \%$ & $93,33^{\mathrm{c}}$ & $6,67^{\mathrm{b}}$ & $6,67^{b}$ \\
\hline GTB local seeds + PGPR concentration $15 \%$ & $100,00^{\mathrm{a}}$ & $7,14^{\mathrm{a}}$ & $0,00^{\mathrm{d}}$ \\
\hline MCC 01 seeds + PGPR concentration $0 \%$ & $96,67^{\mathrm{b}}$ & $6,90^{\mathrm{ab}}$ & $3,33^{\mathrm{c}}$ \\
\hline MCC 01 seeds + PGPR concentration $5 \%$ & $100,00^{a}$ & $7,14^{\mathrm{a}}$ & $0,00^{\mathrm{d}}$ \\
\hline MCC 01 seeds + PGPR concentration $10 \%$ & $96,67^{b}$ & $6,90^{\mathrm{ab}}$ & $3,33^{c}$ \\
\hline MCC 01 seeds + PGPR concentration $15 \%$ & $100,00^{\mathrm{a}}$ & $7,14^{\mathrm{a}}$ & $0,00^{\mathrm{d}}$ \\
\hline BNJ 0,05 & $\mathbf{0 , 0 3}$ & 0,45 & 0,40 \\
\hline
\end{tabular}
PGPR application on two types of cocoa seeds had a very significant effect on seed germination, seed growth speed and abnormal seeds in cocoa. The average parameter results are presented in Table 1.

Table 1. Germination (\%), Seed Growth Speed (\% / etmal) and Abnormal Seed (\%) of cocoa on the 14th day of giving PGPR bamboo rhizosphere to seeds.

Information: The numbers followed by the same letter (abcd) in the same row and column mean not significantly different in the BNJ ${ }_{0.05}$ level test.

BNJ test results Table 1. The interaction between the use of cocoa species and the treatment of bamboo rhizosphere PGPR concentration has a very significant effect on cocoa seed germination. The highest germination parameter was $100.00 \%$, the highest seed growth speed parameter was $7.14 \%$ and the highest abnormal seed parameter was $10.00 \%$.

\section{Use of Two Types of Cocoa Seeds}

In seed germination in the nursery phase, the results showed that the average use of MCC 01 cacao seed type had the highest effect on germination and seed growth speed, while local GTB seeds had the highest effect on abnormal seed conditions. The seeds of MCC 01 had a very significant effect on germination, which was counted twice on the 7 th and 14th day with the highest germination rate of $100 \%$, the observed seed growth rate for 14 days with the fastest seed growth percentage of $7.14 \% /$ etmal and the percentage of abnormal seeds calculated on the 14th day with the highest abnormal seeds, namely $10 \%$. This is due to the influence of the environment where the seeds grow at the time of the nursery, where the humid conditions and long seeding times lead to optimum germination and seed growth speed. In addition, the genetic factor of the seed itself is also a major influence on germination, because if the genetic of the seed is not strong enough to accept the environmental conditions where it is grown and the initial treatment, it will cause the seeds to not have the potential to germinate normally or in other words, abnormal seeds. This is in accordance with Saleh (2004) statement, which states that cocoa has an epigeal germination type, so the time needed to produce radicles greatly affects the speed of procuring ready-to-channel seeds. The process of seed germination is influenced by genetic and environmental factors. The improvement of the external environment will significantly encourage the emergence of radicles as the beginning of the seed 
germination process. The emergence of sprouts above the soil surface is a factor that reflects the vigor of a seedling. To find out which treatment can increase vigor, the sprouts that can appear above the soil surface are observed from the number of seeds germinated.

The average germination rate with the highest effect was the type of MCC 01 seed when compared to the local GTB seed germination capacity. The average seed germination rate in this study had optimum growth because the seeds had been given previous treatment, where the highest germination growth in MCC 01 seeds and local GTB seeds had been treated with PGPR with a concentration of $5 \%$ and $15 \%$. Giving PGPR treatment with the highest concentration is a major factor in the germination power of seeds. This is in line with the opinion expressed by Schmidt (2002), that pre-treatment is carried out with the aim of increasing the power, speed and uniformity of seed germination.

The average seed growth speed with the fastest effect was the MCC 01 seed type when compared to the local GTB seed growth rate. The average seed growth speed of MCC 01 seeds and local GTB seeds with PGPR treatment with a concentration of $5 \%$ and $15 \%$ showed the fastest growing results when compared to other seeds. The growth rate of MCC 01 seeds and local GTB seeds is influenced by the optimum condition of the seeds at the time of the seed nursery and the provision of special treatment for seeds so that the metabolism of seed growth can run well. This is in line with the statement of Lesilolo et al. (2013) stated that the speed of seed growth is a process of rapid reactivation of seeds if the surrounding conditions are for optimum growth and the metabolic process is not hampered.

Abnormal seeds in the use of local GTB seeds without PGPR treatment or control and with PGPR treatment with a concentration of 5\% showed the highest yield of abnormal seed conditions when compared to other seeds. Abnormal seeds occur due to the lack of pre-treatment of local GTB seeds, besides the physical and genetic characteristics of local GTB seeds which tend to be weaker than MCC 01 seeds. The occurrence of abnormal seeds in the nursery process is due to the deterioration of the seeds so that the quality of the seeds decreases which resulting in inhibition of the germination process. This is in line with the statement of Sutopo (2002), that the decline in seeds that occurs indicates a decrease in seed quality or viability which results in low vigor and poor plant growth and production. This is also reinforced by the statement of Debtisari et al. (2018), that abnormal seeds are seeds that are capable of germinating but do not show the potential to develop into normal sprouts. The seed is said to grow abnormally if the important structure for the germination process is lost or damaged, the growth of sprouts is weak due to defective or disproportionate sprouts structure, and sprouts with slow growth until the end of the test. When compared to normal seed sprouts, the abnormal seed growth is smaller than normal sprouts.

\section{Concentration of PGPR Rhizosphere Bamboo on Seeds}

In the germination of seeds in the nursery phase, the results showed that the treatment of seed concentration using the bamboo rhizosphere PGPR had a very significant effect on germination capacity, germination speed, and the percentage of abnormal seeds. This is because the need for PGPR or initial immersion of seeds can result in a more active metabolism of seeds to support germination, besides that the use of PGPR microorganisms can improve seed quality because PGPR acts as a growth stimulant (biostimulant) by synthesizing and regulating the concentration of various regulatory substances. growing (phytohormones) very well on seeds. This is supported by research from Baihaqi et al. (2018) which states that soaking seeds with PGPR is intended so that the bacteria contained in PGPR are able to colonize the seeds as early as possible. The right long soaking treatment can increase plant yield because the bacteria will bind the seedcoat and imbibe it into the seeds.

\section{CONCLUSION}

Giving PGPR bamboo rhizosphere from several concentrations gave different responses to cocoa seed germination including the parameters of germination $(100.00 \%)$, seed growth speed (7.14\%/etmal), and abnormal seeds $(10.00 \%)$. So that seed treatment with bamboo rhizosphere PGPR has an effective effect on cocoa seed germination.

Conflict of interest: The author declares that there are no conflicts of interest concerning the publication of this article.

\section{REFERENCES}

Asniah, Widodo, \& Wiyono S. (2013). Potensi cendawan asal tanah perakaran bambu sebagai endofit dan agen biokontrol penyakit akar gada pada tanaman brokoli. J. Fitopatol Indones. 1 (2): 61-68

Baharuddin, Nur R., \& Sayifudin A. (2007). Pengembangan Usaha Perbenihan Kentang Hasil Kultur Jaringan. FORKOM IPTEKDA LIPI. Makassar: Gedung IPTEK. Universitas Hasanuddin

Baihaqi A.F., Yamika W.S.D., \& Aini N. (2018). Pengaruh Lama Perendaman Benih dan Konsentrasi Penyiraman Dengan PGPR Pada Pertumbuhan dan Hasil Tanaman Mentimun (Cucumis sativus L.). Jurnal Produksi Tanaman. 6 (5): 899905.

Deptisari H.E., Erawati D.N., \& Sugiyarto. (2018). Pengaruh Cara Penyimpanan Terhadap Viabilitas Benih Kakao (Theobroma 
cacao L.) Klon Sulawesi 01. Agropross National Conference Proceedings of Agriculture. Jember: Politeknik Negeri Jember

Effendi M.S. (2011). Kinetika Fermentasi Asam Asetat (Vinegar) oleh Bakteri Acetobacter aceti dari Etanol Hasil Fermentasi Limbah Cair Pulp Kakao, Jurnal Teknologi dan Industri Pangan. 8 (2): 125-135.

Junaedi, Thamrin S., \& Baba B. (2017). Kajian Penggunaan Klon Unggul Kakao Pada Perkebunan Rakyat di Kabupaten Bone. J. Agroplantae. 6 (1): 46-49.

Leisolo M.K.J., Rirydan E.A., \& Matatula. (2013). Pengujian viabilitas dan vigor benih beberapa jenis tanaman yang beredar dipasaran kota Ambon. Jurnal Agrologia, 2 (1): 1-9.

Li Z., Traore A., Maximova S., \& Guiltinan M.J. (1998). Somatic embryogenesis and plant regeneration from floral explants of cacao (Theobroma cacao L.) using thidiazuron. In Vitro Cell. Dev. Biol-Plant. 34: 293-299.

Rouhi H.R., Surki A.A., Sharif-Zadeh F., Afshari R.T., Aboutalebian M.A., \& Ahmadvand G. (2011). Study of different priming treatments on germination traits of soybean seed lots. Notulae Sci Biol. 3 (1): 101-108.
Saleh M.S. (2004). Pematahan dormansi benih aren secara fisik pada berbagai lama ekstraksi buah. Agrosains. 6 (2): 79-83.

Schmidt L. (2002). Guidelines for Handling Tropical and SubTropical Forest Seed Plants. Danida Forest Seed Centre. Krogerupvej 21. DK-3050. Denmark. Humlebaek.

Sugiharti E. (2006). Budidaya Kakao. Bandung: Nuansa.

Sutopo L. (2002). Teknologi Benih. Jakarta: PT Raja Grafindo Persada.

Tefa A. (2017). Uji Viabilitas dan Vigor Benih Padi (Oryza sativa L.) selama Penyimpanan pada Tingkat Kadar Air yang Berbeda. Jurnal Pertanian Konservasi Lahan Kering. 2 (3): $48-50$.

Widyaningrum A. (2017). Pengaruh Aplikasi PGPR (Plant Growth Promoting Rhizobacteria) dan Kompos Azolla Terhadap Mutu Bibit Asal Stek Kopi Robusta. Jember: Fakultas Pertanian Universitas Jember.

Yusniar. (2013). Membangun Kesejahteraan Petani Lewat Nagari Model Kakao (NMK). Padang: Dinas Perkebunan Sumatera Barat. 
THIS PAGE INTENTIONALLY LEFT BLANK 